\title{
Female Literacy and Economic Development in India
}

\author{
Ripudaman Singh \\ Lovely Professional University
}

\begin{abstract}
Role of education and particularly female education in the development process is well documented. Economists of the classical period have also highlighted this association, which is similarly reconfirmed in present times. Besides the social and economic benefits of education, female literacy is considered a bet in improving the health and basic child care. Higher literacy rates show lower poverty ratios amongst different parts of the world. India has also shown a tremendous increase in its literacy rates since independence, but it too holds the largest concentration of poor people in the world. Increasing literacy is considered a harbinger for economic development. This has been postulated to be tested through the case of India. District level analysis of female literacy and its spatial correspondence with asset less population of India in 2011 is ascertained. The present paper attempts to determine the spatial patterns of female literacy and economic development in India. Higher female literacy rate districts are noted for lower proportions of poor populations.
\end{abstract}

Keyword: Asset-less population, economic development, female literacy, India.

\section{INTRODUCTION}

That education promotes development is a proven fact, and female literacy is considered a key instrument in women empowerment and higher social development. But the developing countries, particularly the South Asian countries, which are the most poverty stricken region in the world), are still lagging behind in general literacy and in female literacy. A look at UNDP (2015) data indicates that higher literacy rates show lower poverty ratios amongst these countries (Table 1). India which is largest democracy, second largest in terms of population and the third largest economy (in purchasing power parity) in the world, shows a moderate level of literacy.

Table-1: Literacy and Poverty in South Asia, 2015

\begin{tabular}{lcccc}
\hline Countries & \multicolumn{1}{c}{$\begin{array}{c}\text { Multidimensional } \\
\text { Poverty }\end{array}$} & \multicolumn{3}{c}{ Literacy Rates } \\
& Intensity of deprivation & Adult & Female & Male \\
(15+ age) & (Youth 15-24) & (Youth 15-24) \\
\hline Afghanistan & 49.9 & 31.7 & 32.1 & 61.9 \\
Bangladesh & 47.8 & 58.8 & 81.9 & 78.0 \\
Bhutan & 43.5 & 52.8 & 68.0 & 80.0 \\
India & 51.1 & $\mathbf{6 2 . 8}$ & $\mathbf{7 4 . 4}$ & $\mathbf{8 8 . 4}$ \\
Maldives & 37.5 & 98.4 & 99.4 & 99.2 \\
Nepal & 47.4 & 57.4 & 77.5 & 89.2 \\
Pakistan & 52.0 & 54.7 & 63.1 & 78.0
\end{tabular}


In 2001 around two thirds of India's population were literate which improved to around three fourth in 2011. Literacy differential between male and female literacy rates, which was more than twenty percent points in 2001, was reduced to around sixteen percent points in 2011. Literacy rates are improving fast and the literacy differential is also declining, and areas with higher literacy rates and especially female literacy are found to be high in overall development levels. The present research paper looks into the factors which explain the persistence of higher literacy and economic development in India. It attempts to ascertain the spatial patterns of female literacy and economic development in India. District level data is used to analyze the patterns of female literacy and asset less population for 2011 period.

\section{FEMALE LITERACY IN INDIA}

Of late, it is now an established fact that education plays a significant role in the development process. Earlier also classical economists have highlighted this association in the then developing Europe and America. In recent times, many of the modern scholars, including Becker (1993), Drez and Sen (1995) and Schultz (1988) have also reconfirmed this association. Besides the social and economic benefits of education in general and that of female literacy in specific, the household's ability to manage basic child care, regulate nutrition, and ensuring better health care etc. have been the major advantages. A Chinese proverb aptly signifies the importance of female literacy as "If you plan for a few years, earn money; for ten years, then plant trees; but if you plan for a hundred years, educate the women". This has been validated through the empirical works of Fields (1980), Psachropoulous and Woodhall (1985), and Tilak (1989) that education plays a great role in reducing absolute poverty. Similarly, researchers like Birdsall et al. (1992), Pudaisani (1992), Baro and Sala-i-Martin (1995) found that overall educational development leads to increase in national incomes and its economic development. In case of India, it was also observed that a year's increase in the usual number of years of primary education of workforce raised 23 percent output. The case of Kerala may also be highlighted in displaying how higher literacy of females was impacting on poverty reduction. On the other hand states such as Bihar, low on female literacy have deteriorated in mass poverty. Affirmative association between female literacy and family planning is also perceived and considered as a positive indicator of population control and management (Govt. of India, 1993). Educating the females is certainly a dependable indicator of the social advancement of any region in general.

Indian Census of 2011 registered 74.80 per cent of the $7+$ age group population as literate, which was 65.40 percent a decade earlier in 2001. A wide gap of more than 20 percent points between the male literacy rates $(75.65 \%)$ and that of female literacy rates $(54.16 \%)$ were witnessed in 2001 census, which has been reduced to 16 percent points among the male literacy rates $(82.14 \%)$ and female literacy rates $(65.46 \%)$ in 2011 (Table 2 ). This pattern of wide gap between male and female literacy is archetypal of all cultures having a stout male dominance base where advancement of the females is considered a more subtle index of social transformation (Singh, 2016).

Female literacy rates at the state level, were recorded highest in the western coastal regions of Kerala, Goa, Maharashtra, Gujarat and Karnataka. In the North Eastern region, 
Mizoram, Tripura, Nagaland, Sikkim, Meghalaya and Manipur also recorded high female literacy. Amongst Northern states, Delhi, Himachal Pradesh, Uttrakhand, Punjab and Haryana also noted higher female literacy. On the other hand, Odisha, Chhattisgarh, Andhra Pradesh, Madhya Pradesh, Arunachal Pradesh, Jammu \& Kashmir, Uttar Pradesh, Jharkhand, Rajasthan and Bihar were distinguished for lower female literacy rate, below the national average (65.46 \%). Rajasthan and Bihar recorded little more than 50 percent female literacy rates. Amongst the districts, Pathnamthitta (92 \%) in Kerala recorded the uppermost female literacy rates while the lowermost rates were registered in Jagatsinghapura district (12\%) of Odisha.

Map 1 depicts that around two third districts of the country registered female literacy rate above 50 percent. All such districts are clustered in the coastal belt, Northwestern parts and Northeastern India, besides the large urban concentrations along Mumbai-Kolkata Corridor. Million Cities and the union territories are noted for relatively greater levels of female literacy. Majority of districts located along the western coast, in the states of Kerala, Karnataka, Goa, Maharashtra and Gujarat and its extension in state of Tamil Nadu carve a cluster of higher female literacy levels. Such areas were noted for early improvement in female education in India (Gosal, 1979).

Amongst the North Indian states, Delhi, Haryana, Punjab, Himachal Pradesh, Western Uttar Pradesh region and Uttarakhand presents another clustered zone of higher female literacy rates. Such areas are those where we have a tradition of army service and agricultural development based on Green Revolution during the sixties, led to higher rates of literacy inclusive of female literacy rates too (Gosal, 1979).

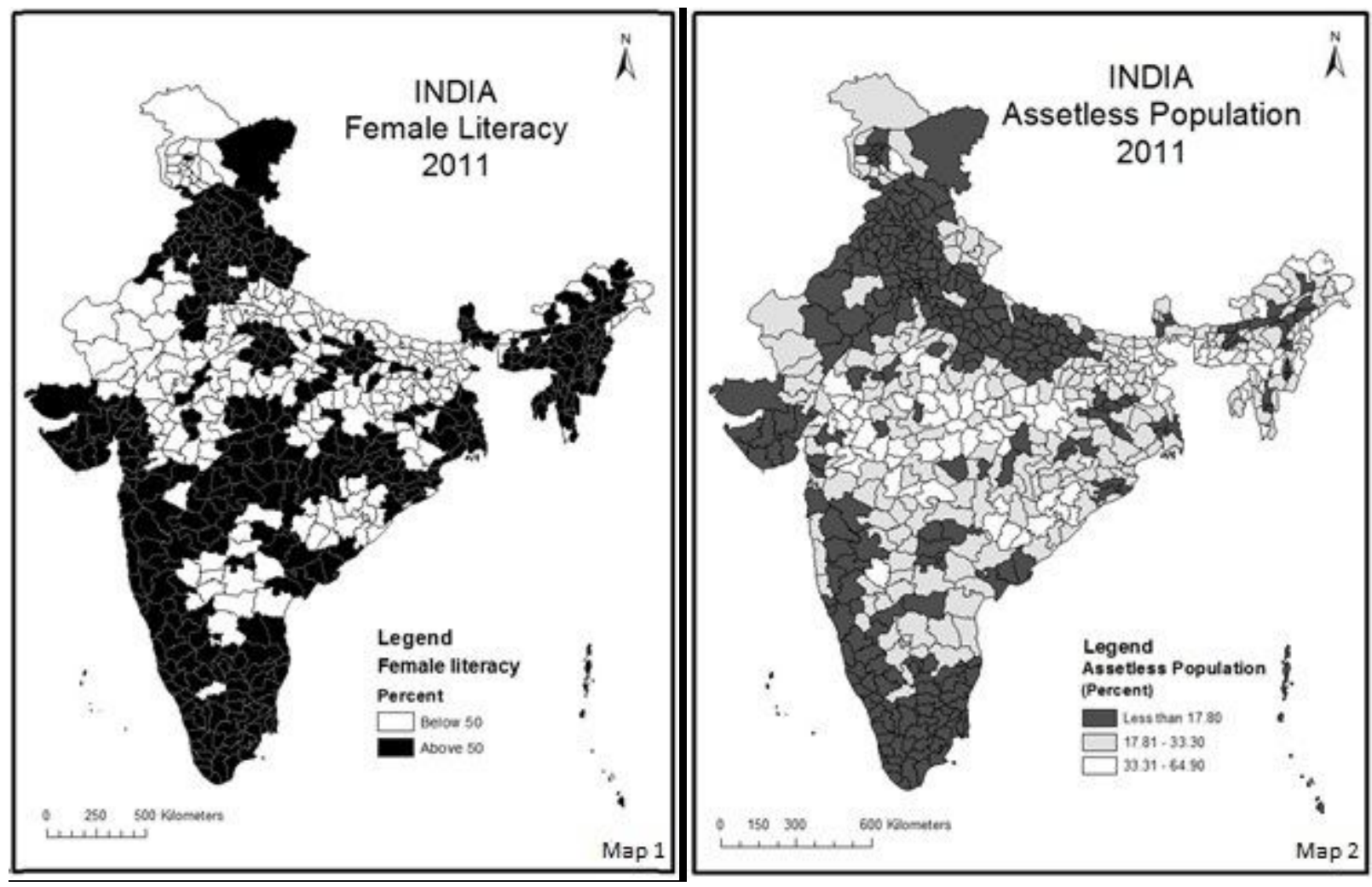

Higher literacy rates amongst the women are also witnessed in the Christian dominated states of Mizoram, Meghalaya and Nagaland in the North-Eastern India. Except few districts of Arunachal Pradesh and Assam, all districts noted above 50 percent female literacy rates. Calcutta (Kolkata) 
conurbation in the east, and the coastal plains of Odisha also show high female literacy rates. Mumbai-Kolkata corridor also depicts similar higher female literacy along with the major urban centers.

Compare with the regions of high female literacy, most of Bihar, Jharkhand, majority of Chhattisgarh, Andhra Pradesh, eastern parts of Uttar Pradesh, majority districts of Rajasthan and Jammu \& Kashmir (except Jammu, Srinagar and Leh districts), registered lower levels of female literacy rates. Amongst the leading factors in these areas, desert conditions, hilly terrain, nonChristian tribal concentrations and extreme poverty etc were limitations to the growth of literacy and particularly the female literacy rates.

Table-2: INDIA: Female Literacy and Asset less Population, 2011

\begin{tabular}{|c|c|c|c|c|}
\hline States & Male & Literacy Female & Gap (M-F) & Asset less Population \\
\hline Kerala & 96.02 & 91.98 & 4.04 & 7.1 \\
\hline Mizoram & 93.72 & 89.40 & $4 \cdot 32$ & 20.4 \\
\hline Tripura & 92.18 & 83.15 & 9.03 & 14.1 \\
\hline Goa & 92.81 & 81.84 & 10.97 & 5.1 \\
\hline Delhi & 91.03 & 80.93 & 10.10 & $9 \cdot 9$ \\
\hline Nagaland & 83.29 & 76.69 & 6.60 & 18.9 \\
\hline Himachal Pradesh & 90.83 & 76.60 & 14.23 & 8.1 \\
\hline Sikkim & 87.29 & 76.43 & 10.86 & 8.2 \\
\hline Maharashtra & 89.82 & $75 \cdot 48$ & 14.34 & 17.4 \\
\hline Tamil Nadu & 86.81 & 73.86 & 12.95 & 11.3 \\
\hline Meghalaya & 77.17 & $73 \cdot 78$ & 3.39 & 11.9 \\
\hline Manipur & 86.49 & 73.17 & 13.32 & 36.9 \\
\hline Punjab & 81.48 & 71.34 & 10.14 & 8.3 \\
\hline West Bengal & 82.67 & 71.16 & 11.51 & 20.0 \\
\hline Gujarat & 87.23 & 70.73 & 16.50 & 16.6 \\
\hline Uttarakhand & 88.33 & 70.70 & 17.63 & 11.3 \\
\hline Karnataka & 82.85 & 68.13 & 14.72 & 20.9 \\
\hline Assam & 78.81 & 67.27 & 11.54 & 31.9 \\
\hline Haryana & 85.38 & 66.77 & 18.61 & 11.2 \\
\hline Odisha & 82.40 & 64.36 & 18.04 & 32.6 \\
\hline Chhattisgarh & 81.45 & 60.59 & 20.86 & 39.9 \\
\hline Madhya Pradesh & 80.53 & 60.02 & 20.51 & 31.7 \\
\hline Andhra Pradesh & $75 \cdot 56$ & 59.74 & 15.82 & 9.2 \\
\hline Arunachal Pradesh & 73.69 & $59 \cdot 57$ & 14.12 & $34 \cdot 7$ \\
\hline Uttar Pradesh & 79.24 & 59.26 & 19.98 & 29.4 \\
\hline Jammu \& Kashmir & 78.26 & 58.01 & 20.25 & 10.4 \\
\hline Jharkhand & 78.45 & 56.21 & 22.24 & 36.9 \\
\hline Bihar & 73.39 & $53 \cdot 33$ & 20.06 & $33 \cdot 7$ \\
\hline Rajasthan & 80.51 & 52.66 & 27.85 & 14.7 \\
\hline INDIA & 82.14 & 65.46 & 16.68 & 17.8 \\
\hline
\end{tabular}


Majority of such areas are generally observed as lagging behind the other parts of India in terms of their demographic transition stage, as well as, are lower on economic growth, and still slower on diversification of their rural economies (Singh, 1998). The belly of India (i.e., Central India) otherwise distinguished for lower female literacy rates, similarly display several moderately urbanized districts like that of Bhopal, Indore, Hoshangabad, Jabalpur and Ujjain which exhibit moderately high general literacy rates and female literacy in particular.

\section{ECONOMIC DEVELOPMENT IN INDIA}

United Nations and World Bank describe the 'poor population' as 'population which do not have any access to clean drinkable water, any access to facilities for therapeutic and pre-emptive health care and therefore suffer from various rampant diseases, and additionally, they are unaware and ignorant or remain illiterate for lacking any access to using facilities for educating their younger generations and adults' (UNDP, 2008 and World Bank, 2008)). Government of India defines the poor as 'those population which are not getting enough energy in terms calories from cereals, cooking oil, sugar and such other eatable food items in maintaining themselves in good health and also an official poverty line is defined, which essentially represents the price of bag of such commodities with the share of spending on food items of more than $80 \%$ and $20 \%$ for other essential items such as housing and clothing. Provision of 2400 calories in the rural areas and also 2100 calories in an urban area for each individual is measured as a slandered. Similarly, the Planning Commission of India (1979) driven out these calories to the equivalent of Rs. 49.09 per day per person for the population in rural areas and Rs. 56.64 for the populations residing in urban areas, at the constant prices for 1973-74 year. Census of 2001, found at least a quarter of its population below poverty line. Recently in Census of India, 2011, asset-less population have been counted at district level. Around one sixth of its population is counted as asset less, which is 17.80 percent of the total population of India in 2011. For analyzing economic development of India, asset-less population has been taken as a suitable indicator.

Map 2 depicts the spatial patterns of asset-less population in India in 2011. One sixth of its population is asset less, which means this population do not own any of the assets required in daily life, that means no bicycle or vehicle, no TV or radio, no refrigerator or washing machine, no phone or mobile or even bank accounts etc. Northern, southern and western districts are comparatively well off. Central and interior parts of India and majority of North Eastern hill districts recorded higher proportions of asset less populations.

Northern states of Delhi, Haryana, Punjab, Himachal Pradesh and surrounding parts of Uttar Pradesh, Jammu \& Kashmir and Rajasthan have recorded asset less population below national average (17.80 percent). Most of these parts are having agricultural developments in plain areas and tourism in hill states. In the south, Kerala, Tamil Nadu and parts of Coastal Karnataka also recorded lower asset less populations. These areas are high in social development indicators. Coastal Maharashtra, Goa and Gujarat, industrial development is more pronounced in these states as well as Goa is the tourism hub in India. Amongst the North Eastern states, capital city districts and surrounding areas also noted low proportions of poor populations. All districts falling in the low asset less population clusters depict spatial correspondence with districts having more than 50 percent literacy rates (Map 1 and Map 2).

Compare to these clusters of well off areas, majority of districts in Bihar, Jharkhand, West

Bengal, Odisha, Chhattisgarh, Madhya Pradesh and Andhra Pradesh documented high proportions of asset less populations. These areas are noted for naxalite insurgencies owing to 
lower levels of development, tribal concentrations and lower urbanization and infrastructural base. Advent of the red corridor in these states of India is a dire consequence of widening regional disparities in the recent times (Singh, 2015). Majority of North Eastern hill districts also recorded high asset-less populations. These are also insurgency affected areas located in high hills having fragile ecologies and lacking basic infrastructure and industries. Certainly, the areas having high proportions of asset less populations are low in female literacy and overall literacy.

There is no dearth of literature indicating that overall educational development leads to increase in national incomes and its economic development and especially the female literacy. In developing countries generally the male literacy are quite high than the female literacy rates. So higher female literacy rates prove to be a sure bet for increased economic development. In case of India, it has already been observed that a year's increase in the usual number of years of primary education of workforce raised about a quarter output. Exemplary case of Kerala rightly exhibit how female literacy was useful in reducing poverty in the state. Contrast to Kerala's case are the backward states like Bihar and Jharkhand which are having lower female literacy rates have higher poverty ratios and asset less populations. Positive association between female education and family planning is already verified. Controlled population certainly records for increased economic growth and higher levels of development in the long run.

\section{CONCLUSION}

Analysis of district level data of India for female literacy rates and asset less population confirms a spatial correspondence with each other. Higher female literacy rate districts also record lower proportions of asset less populations in India. Majority of districts with more than 50 percent female literacy rates are noted for below national average asset less populations. This spatial correspondence between female literacy and asset less populations represents an inverse correlation. Kerala model of social development should be followed to achieve higher economic development and reducing poverty in the backward states of India. Increased female literacy would be very useful in controlling the population in the BIMARU states. Controlled population certainly lead to increased economic growth and higher levels of development in the long run. As a policy implication it may be suggested that efforts may be made to achieve higher literacy and female literacy along with the general literacy in backward parts of India. Literate women will lead higher social advancement and further leading to higher economic development in India.

\section{REFERENCES}

Barro, A. M. and X. Sala-i-Martin (1995). Economic Growth. McGraw Hill, New York.

Becker, G. S. (1993). Human Capital. The University of Chicago Press, Chicago.

Birdsall, N. et. al. (1992). Underinvestment in education: How much growth has Pakistan forgone? Paper presented at the Ninth Annual General Meeting of the Pakistan Society of Development Economists. Islamabad, January 1992.

Census of India, 2011. Primary census abstract data tables, 2011. New Delhi: Government of India. Retrieved from http://www.censusindia.gov.in/2oncensus/PCA/PCA_Highlights/pca_highlights_india.html

Debroy, B. (2012). Gujarat-the growth story. Indicus white paper series. New Delhi: Indicus Analytics.

Drez, J. and A. Sen (1995). India: Economic Development and Social Opportunity. Oxford University Press, New Delhi.

Fields, G. (1980). "Educational and income distribution in developing countries: a review of the literature", in T. King (ed.), Education and Income. World Bank Working Paper No. 402, Washington, DC. 
70 | Female Literacy and Economic Development in India

Gosal, G. S. (1979). Spatial Perspectives on Literacy in India. Population Geography, 1(1): 41-67.

Government of India (1993). Education for All: The Indian Scene. Ministry of Human Resource Development, New Delhi.

Psachropoulous, G. and M. Woodhall (1985). Education for Development: An Analysis of Investment Choices. World Bank, Washington, DC.

Pudaisani, S. (1982): Education and Agricultural Efficiency in Nepal. World Bank Discussion Paper No. 82-3, Washington, DC.

Schultz, T. P. (1988). "Education, investments and returns", in H. B. Chenery and T. N. Srinivasan (eds.) Handbook of Development Economics. Vol. 1 \& 2, Holland, Amsterdam.

Singh, R. D. (2009). Trends in regional disparities in India since independence a geographical analysis. $\mathrm{PhD}$ Thesis submitted to Faculty of Arts, Panjab University. Chandigarh: Panjab University.

Singh, R. D. (2015). Regional disparities in post reform India. Modern Geografia, 2015/II, 41-68. Retrieved from http://www.moderngeografia.eu/wp-content/uploads/2015/04/2015_II_03_ripudaman.pdf

Singh, R. D. (2016). Regional Disparities in Pre and Post Reform India. Sapatrishi Publications: Chandigarh.

Tilak, J. B. G. (1989). Education and its relation to Economic Growth, Poverty and Income Distribution: Past Evidence and Further Analysis. World Bank Discussion Paper No. 46, Washington, DC.

UNDP. (2008). Human development report, 2008: Fighting climate change: Human solidarity in a divided world. New York, NY: United Nations Development Program.

UNDP. (2015). Human development report, 2015: Work for human development. New York, NY: United Nations Development Program.

World Bank. (2008). World development report, 2008: Agriculture for development. Washington DC: The World Bank.

Dr. Ripudaman Singh is an Assistant Professor in Geography, Lovely Professional University. 